\title{
Enhanced Fire-Related Traits May Contribute to the Invasiveness of Downy Brome (Bromus tectorum)
}

\author{
Annamária Fenesi, Sandra Saura-Mas, Robert R. Blank, Anita Kozma, Beáta-Magdolna Lózer, and Eszter Ruprecht*
}

\begin{abstract}
Although several invasive species have induced changes to the fire regime of invaded communities, potential intraspecific shifts in fire-related traits that might enhance the invasion success of these species have never been addressed. We assumed that traits conferring persistence and competitiveness in postfire conditions to downy brome, a quintessential invasive species of the Great Basin (North America), might be under selection in areas with recurrent fires. Therefore, we hypothesized that populations from frequently burned regions of the Great Basin would have (1) greater tolerance to fire at seed level, (2) higher relative seedling performance in postfire environments, and (3) greater flammability than unburned Central European populations that evolved without fire. Seeds were collected from three introduced populations from frequently burned regions in North America and three introduced populations of rarely or never burned sites from Central Europe. We performed (1) germination experiments with seeds subjected to the effect of different fire components (heat shocks, smoke, flame, ash), (2) pot experiments analyzing the effect of postfire conditions on the early growth of the seedlings, and (3) a series of flammability tests on dry biomass of plants reared in a common garden. All seeds tolerated the low-temperature treatments (40 to $100 \mathrm{C}$ ), but were destroyed at high heat shocks $(140$ and $160 \mathrm{C})$. Only the $100 \mathrm{C}$ heat treatment caused a difference in reaction of seeds from different continents, as the European seeds were less tolerant to this heat shock. We found significantly increased seedling height and biomass after $4 \mathrm{wk}$ of growth under postfire conditions in American populations, but not in European ones. American populations had enhanced flammability in three out of five measured parameters compared to European populations. In summary, these intraspecific differences in fire-related traits might contribute to the persistence and perhaps invasiveness of the frequently burned North American downy brome populations.
\end{abstract}

Nomenclature: Downy brome, Bromus tectorum L. BROTE.

Keywords: Cheatgrass, germination, heat shock, ignitability, invasion.

Nonnative species are now present in most ecosystems, and through native species replacement and changes in abiotic processes, can ultimately cause ecosystem-level transformations (Vilà et al. 2011). The impacts of invasive species are particularly dramatic when they induce shifts in disturbance regimes beyond the range of variation to

DOI: $10.1614 /$ IPSM-D-16-00006.1

* First, fourth, fifth, and sixth authors: Senior Lecturer, Graduate Student, Graduate Student, and Associate Professor, Hungarian Department of Biology and Ecology, Babeş-Bolyai University, Republicii street 42, RO-400015 Cluj-Napoca, Romania; second author: Senior Lecturer, Center for Ecological Research and Forestry Applications and Unit of Ecology, Department of Animal and Plant Biology and Ecology, Autonomous University of Barcelona, E-08193 Bellaterra, Barcelona, Spain; third author: Research Soil Scientist, U.S. Department of Agriculture-Agricultural Research Service, Great Basin Rangelands Research Unit, 920 Valley Road, Reno, NV 89512. Corresponding author’s E-mail: fenesi.annamaria@gmail.com which native species are adapted (Brooks et al. 2004). Such system-altering species are those invaders that cause erosion, change water and nutrient cycling, or alter wildfire regimes (Vitousek 1990). Alien annual grasses, especially, have induced shifts to the frequency and intensity of wildfires, cascading into a host of ecosystem perturbations (D'Antonio and Vitousek 1992; Pausas and Keeley 2014).

Plants growing in environments with different fire characteristics, such as length of time between fire events and intensity of fire, may alter several life-history traits and evolve ecotypes to maximize survival and fitness (Blank et al. 2006). Such morphological and physiological adaptations, evolved due to selective pressure of fire, can be related to seed dormancy, serotiny, fire-induced germination, seed fire tolerance, flammability, or resprouting ability. Recent studies have shown that adaptation to fire can occur even in a very short period of time. For example, seed morphology and anatomy (Gómez-González et al. 


\section{Management Implications}

We provide evidence that North American downy brome populations from frequently burned environments have enhanced postfire biomass accumulation and flammability compared to European populations that are rarely or never exposed to fire. Seeds of downy brome, however, do not tolerate severe fires with high heat shocks.

Our results suggest that management should focus on changing the fire regime toward less frequent, but more intense, fires to stop this highly invasive species. Therefore, lengthening the fire-return interval by creating firebreaks, which would amplify the intensity and size of subsequent fires, may be one option for controlling this invasive species. However, such bands of fuel breaks, where fuels are removed by cutting several swaths to reduce fire hazard, can serve as refuge and seed source of downy brome. The association of fuel breaks with roadways might minimize the total landscape impact.

To prevent the germination of downy brome, persistent cover of the ground by native vegetation must be achieved by reintroducing fire-tolerant perennial grasses and resprouting shrubs such as rabbitbrush, as closed vegetation makes for very limited alien seedling recruitment opportunities. The fire management practice should target the historical, natural fire regime that favors native species reestablishment. These native species would produce higher fuel loads and a continuous fuel bed that might also increase the intensity and decrease the frequency of fires.

Although our results may suggest that the introduction of European, non-fire-adapted populations of downy brome to the United States might be an option, they would perhaps be outcompeted in short time by the fire-adapted local genotypes. The North American populations are further expected to increase flammability of stems and leaves if frequent and low-intensity fires persist in the invaded territories.

2011), serotiny (Hernandez-Serrano et al. 2013), and flammability (Pausas et al. 2012) have proven to adaptively change in a short time span due to recurrent anthropogenic fires. Despite the fact that invasive species are considered to have substantial evolutionary potential (Maron et al. 2004; Prentis et al. 2008), and that the success of these species is positively linked to the more frequent fire regimes they have induced (D'Antonio 2000 and literature therein), the intraspecific variability of traits linked to different fire regimes (Pausas et al. 2012) has never been addressed in annual invasive grass species. Shifts in fire-related traits might help these fire-promoted and fire-promoting species to further enhance their invasion success.

In arid and semiarid regions of western North America, the invasive annual grass downy brome (Bromus tectorum L.) has largely been responsible for dramatic ecosystem alteration on over 10 million hectares (Billings 1994). A winter annual, downy brome germinates during autumn and finishes its life cycle by spring-early summer, several weeks before native grass species (Knapp 1996). By producing a large quantity of fine fuels and increasing the horizontal continuity of those fuels, downy brome changes both the seasonality of fire (earlier fires) and increases the fire frequency (more frequent fires) of the invaded communities (D’Antonio and Vitousek 1992). For example, wildfires historically occurred every 50 to $70 \mathrm{yr}$ in sagebrush communities in the Great Basin, and with the invasion and expansion of downy brome the fire frequency in these community types has increased to intervals of 2 to 5 yr (Young and Evans 1978; Young et al. 1972). Downy brome thrives under the new conditions created by its burned biomass (competition-free microhabitats, soil surface covered by its own charred biomass, elevated nitrogen availability), developing a new, alternative selfperpetuating stable state (Westoby et al. 1989). This altered state changes the community properties to the point where native species cannot recover (Brooks et al. 2004; Pausas and Keeley 2014).

Here, we hypothesize that introduced downy brome populations subjected to frequent fires show enhanced fire response characteristics compared to introduced populations that are rarely or never under fire pressure. Increase in fire response characteristics in downy brome assumes shifts in a complexity of traits that enhance the survival and success of individuals in populations with recurrent fires. We assume that fire tolerance of seeds, enhanced postfire growth, and enhanced flammability are important attributes among the fire-related traits that might confer advantages to this invasive species.

Theory predicts that flammability traits could evolve if fire spreads from a flammable plant and more-flammable mutants recruit into the gaps created by fire ("kill thy neighbor" hypothesis; Bond and Midgley 1995). Additionally, flammability was proposed as a niche-construction trait, because as fuel, plants can influence the nature of fire they experience, and thus impact their own environment in a way that might influence offspring establishment and performance (Laland et al. 1999). Enhanced flammability can confer direct benefits in the form of reduced competition and advantageously alter the microenvironment for the offspring, while the cost of pyrogenicity might be the potential tissue loss from the increased likelihood of burning (Gagnon et al. 2010). However, as a winter annual, downy brome does not risk damage to aboveground tissues during summer fires, its life cycle being already completed by that time. Thus, in this case, the relative cost or gain of enhanced flammability in fire-prone habitats will exclusively be a function of offspring safety and performance.

Based on the above-mentioned theories, flammable plants should have solid postfire regeneration strategies to benefit from high resource availability and low competition created by fire. The ability to resprout and the regeneration from seeds are the two mechanisms of postfire recovery (Lloret et al. 2005). Downy brome, being an annual, is an 


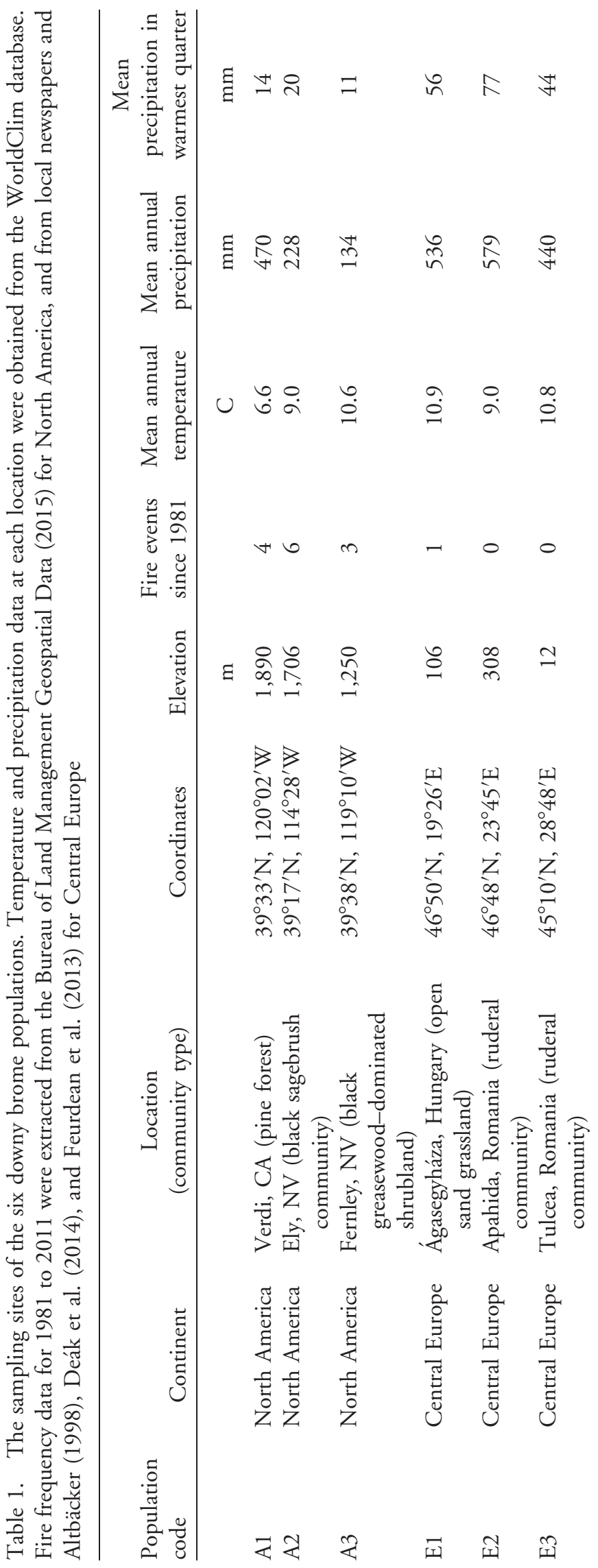

obligate seeder species, thus its persistence in burned sites depends exclusively on the survival of seeds during fire and on the recruitment success of new individuals in postfire conditions (Pausas et al. 2004). The frequency and intensity of fire may selectively shape seed traits that could be involved in fire resistance (Gómez-González et al. 2011), as positive correlations were found between fire regime and seed persistence (Climent et al. 2004; GómezGonzález et al. 2011; Lloret et al. 2005). Therefore, fire resistance of downy brome seeds can be an adaptive response to fire in frequently burned ecosystems that allows efficient germination and establishment after fire (Keeley et al. 2011). In addition, postfire seedling performance can also be an adaptive response in frequently burned areas. Earlier studies found that seedlings developed after heat or smoke treatment showed enhanced growth (Escudero et al. 2000; Moreira et al. 2010).

Therefore, we planned a study to compare fire tolerance of seeds, seedling growth after fire, and flammability in several downy brome populations with different fire histories. We collected seeds from three introduced populations of downy brome from the Great Basin in the western United States (Nevada and California), which have experienced frequent fires for the last $30 \mathrm{yr}$ (three, four, or six fires between 1981 and 2011; Table 1; Bureau of Land Management 2015). To serve as a control, we also collected seeds from three Central European populations (Romania and Hungary), which have not experienced fire for the last $30 \mathrm{yr}$ (Table 1). In temperate regions of Central Europe there are no fire-prone ecosystems, thus there are no natural fires. Anthropogenic fires are rare and act only locally (Deák et al. 2014; Feurdean et al. 2013).

We formulated hypotheses regarding the responses of different downy brome populations to our treatments, as follows:

Hypothesis 1. Seeds of downy brome from frequently burned North American regions have greater tolerance to fire than seeds from Central Europe where fire is very rare or absent. This hypothesis was tested in germination experiments with seeds subjected to the effects of different fire components (heat shocks, smoke, flame, ash; experiment 1).

Hypothesis 2. Downy brome seedlings from frequently burned North American regions have higher relative seedling performance in postfire environments than seedlings from European ecosystems where fire is absent or very rare. This hypothesis was tested in a pot experiment analyzing the effect of postfire conditions (soil chemistry modified by ash) on the early growth of the seedlings from populations with different fire regime (experiment 2). 
Hypothesis 3. Biomass of downy brome originating from North America has greater flammability than that from Central Europe. This hypothesis was tested through a series of flammability tests on dry biomass of plants reared in a common garden (experiment 3).

\section{Materials and Methods}

The Study Species. Downy brome is a cleistogamous, winter annual grass species, native in the arid steppe region of Europe (southern Europe and the Mediterranean region), the Middle East, and the temperate and tropical part of Asia (Kaczmarski 2000). However, it is a longestablished adventive species (archaeophyte) in Central European countries (Terpó et al. 2000). Moreover, downy brome was first reported in North America in 1790 (Bartlett et al. 2002), and since has become one of the most important invaders in the western United States (Mack 1981). Genetic analyses have demonstrated multiple introductions of this species into North America (Bartlett et al. 2002; Novak and Mack 1993, 2001) and source populations were drawn exclusively from Europe, either from populations in the western Mediterranean or Central Europe (Novak and Mack 1993). Seeds of downy brome germinate rapidly with the first fall or winter precipitation, overwinter as seedlings, and grow rapidly in the spring until flowering at the beginning of summer.

Caryopses (hereafter seeds) of downy brome were collected from at least 50 to 100 individuals from three North-American populations in 2011 (A1, A2, and A3 populations), and from three Central-European populations in 2012 (E1, E2, and E3 populations; Table 1). All seeds were kept in paper bags and stored at room temperature until used in the experiments. The fire frequencies for North American populations between 1981 and 2011 were extracted from the georeferenced fire history database of the Bureau of Land Management for the state of Nevada (Bureau of Land Management 2015). Fire frequencies were calculated in a 5-km-radius (3.1-miradius) circle around the collection site. Note that all American sites have been invaded by downy brome and the fire frequency reported in Table 1 is a modified fire frequency by the dominance or high abundance of downy brome. The fire histories of European populations were extracted from local newspapers and scientific literature (Altbäcker 1998; Deák et al. 2014; Feurdean et al. 2013). In Central Europe (including Romania) there are no natural fires due to the temperate climate; therefore, fire events are rare and are always anthropogenic.

Climate data were extracted from WorldClim database (http://www.worldclim.org, Hijmans et al. 2005). Central Europe has a continental climate with hot summers and cold snowy winters, whereas the climate in the Great Basin of North America is semiarid or arid with warm summers and cold winters (Table 1).

Experimental Design. Experiment 1. Germination Response to Different Fire Components. During burning, the freshly shed seeds experience direct flame and high temperatures at the soil surface or in the litter, and then germinate in light conditions if they survive, whereas those buried in the soil are affected by lower heat shock and germinate in the dark. We simulated these two situations by heating the seeds of all six populations in an oven for $5 \mathrm{~min}$ at (1) low temperatures $(40,60,80 \mathrm{C}[104,140,186 \mathrm{~F}])$ and then allowing them germinate in the dark, simulating seeds burned in the soil and (2) at high temperatures (100, 120, $140,160 \mathrm{C})$ and letting them germinate in light conditions, simulating the fate of seeds in the soil surface or in the litter. The temperatures were chosen to simulate the condition of fires in sites dominated by downy brome in the Great Basin: at $5 \mathrm{~cm} \mathrm{(2} \mathrm{in)} \mathrm{above} \mathrm{soil,} 150$ to $160 \mathrm{C}$; at the soil level 125 to $140 \mathrm{C}$; in the soil at $-1 \mathrm{~cm}, 60$ to 70 C; and at $-3 \mathrm{~cm}, 50$ to $60 \mathrm{C}$ ) (Beckstead et al. 2011).

We also tested the effect of direct flame, ash, and smoke on the germination proportion of seeds from different populations. During the direct flame treatment (simulating seeds trapped in the litter), seeds were held with a tweezers one at a time and placed in the flames of a Bunsen-type burner for $1 \mathrm{~s}$ at a constant $10-\mathrm{cm}$ distance from the source of the flame. The temperature reached 300 to $400 \mathrm{C}$ during the 1-s exposure to the flame. Ash was prepared by burning $15 \mathrm{~g}(0.5 \mathrm{oz})$ downy brome biomass (E1 European source population, Table 1) on a hot plate until no plant material was left for further combustion. Ash $(0.5 \mathrm{~g})$ was ground to pass a 2 -mm $(0.08$-in) mesh sieve and then leached overnight in $100 \mathrm{ml}(3.4 \mathrm{oz})$ distilled water to get a $0.5 \%$ solution. This aqueous suspension, which simulated charred wood, was applied to seeds on filter paper (Keeley and Fotheringham 1998; Pérez-Fernández and RodríguezEcheverría 2003).

During the smoke treatment, we burned $15 \mathrm{~g}$ downy brome biomass (whole aboveground parts) in a $180-\mathrm{mm}$ glass pan. A glass funnel with a $180-\mathrm{mm}$ diameter was placed upside down on the pan and smoke escaped through a thin, 0.5-m-long, 15-mm-inside diam rubber hose, which fed into a 30-L (1014-oz) glass chamber where the seeds (and the filter papers) were placed. After $5 \mathrm{~min}$ of filling, all ports were sealed and seeds were incubated for 20 $\min$.

Six replicates of 30 seeds per population were subjected to each treatment described above (heat shocks, flame, ash, 
and smoke), then placed on two layers of filter paper in 8$\mathrm{cm}$-diam petri dishes. The germination of treated and untreated seeds (control) was carried out in germination chambers (Sanyo MLR-352H, Sanyo/Panasonic Healthcare Co., Ltd., Oizumi, Japan) providing a photosynthetic photon flux density of approx. $250 \mu \mathrm{mol} \mathrm{m}^{-2} \mathrm{~s}^{-1}$. One germination chamber was set at an alternating 25/15 C temperature with a $16 \mathrm{~h}$ light $/ 8 \mathrm{~h}$ dark photoperiod for high heat shocks, direct flame, ash, and smoke treatments, while another chamber at the same temperatures had constant dark for low heat shock treatments. In both chambers we germinated six control seed sets for each population. Filter papers were kept moistened throughout the germination test $(27 \mathrm{~d})$ and every 3 to $4 \mathrm{~d}$ seeds showing radicle protrusion were counted and removed. The location of the dishes in the chamber was randomized at the beginning of the experiment and dishes were kept in that position for the rest of the study.

The genetic background and growth environment of mother plants can affect germination of seeds and interfere with the effect of experimental treatments (Dlugosch and Parker 2008). We used a mix of seeds collected from 50 to 100 randomly chosen individuals per populations, thus sampling the genetic pool at the population level and thus minimizing the effect of individual genetic maternal effects of mother plants. Moreover, prior to the experiments, a subset of seeds from each population was weighed (50 seeds were weighed six times to $10^{-4} \mathrm{~g}$ ). The averaged individual seed weight per population was used as a covariate in subsequent analyses, as seed mass may be influenced by the size and physiological conditions of the mother plant, and thus can be used as a good surrogate of maternal performance (Mousseau and Fox 1998).

Experiment 2. Early Growth after Fire. We conducted a controlled pot experiment of fire effects on seedling early growth. One-liter pots were filled with a 2:1 mixture of commercial potting soil and sand in 12 replicates for each population. Ten downy brome seeds were put on the soil surface in March 2013, and half of the pots were arranged randomly and covered by dry litter (3 g per pot; $365 \mathrm{~g}$ $\mathrm{m}^{-2}$ ), and then the litter was burned. The other half of the pots were untreated and used as a control. Litter was collected from xero-mesic grasslands near Cluj-Napoca, Romania, which do not contain downy brome, because we wanted to rule out any possible confounding effect caused by using the litter from one chosen European population of downy brome. Four equidistant seedlings (at least $5 \mathrm{~cm}$ of distance between seedlings) were kept during the peak germination period, and grown for $4 \mathrm{wk}$, while the superfluous seedlings were pulled out. Treated and control pots were arranged using a randomized block design in three frames made of wood (blocks), and covered with a transparent polyethylene sheet in the University Botanical Garden in Cluj-Napoca. Pots were regularly watered. After $4 \mathrm{wk}$ of growth, we measured the height of shoots, then all individuals were harvested, roots were washed free of soil, dried for $48 \mathrm{~h}$ at $60 \mathrm{C}$ and weighed.

\section{Experiment 3. Flammability of Aboveground Biomass.} Biomass required to conduct flammability tests was produced under controlled conditions in an outdoor experimental area in the University Botanical Garden in Cluj-Napoca, Romania. Seeds $(n=500)$ from each population were separately and uniformly broadcast on the surface of soil beds ( 100 by 60 by $30 \mathrm{~cm}$ ) in October 2012. Soil beds were arranged next to each other in a 2 by 3 design and populations were subjected to the six blocks in a random manner. Seeds germinated in November 2012 and overwintered in a two-leaved stage. Plants were kept until seed set and biomass was dry in June 2013. Blocks were uniformly watered twice a week.

Aboveground parts of downy brome individuals with fully ripened seeds and dead biomass from the six populations were cut and kept under ambient conditions in paper bags. Plant samples from each separate population were cut into approximately $1-\mathrm{cm}$ pieces and homogenized. The flammability of aboveground biomass from each population was tested with a quartz epiradiator (Saura-Mas et al. 2010), which progressively releases rising heat and induces a spontaneous fire event in three phases: (1) smoke phase (appearance of smoke at the time when pyrolysis starts), (2) smoldering phase (start of the combustion, marked by the appearance of red spots), and (3) flaming phase (appearance of flames). One gram of biomass was placed on a wire mesh at a distance of $4 \mathrm{~cm}$ from the epiradiator source. A thermocouple positioned in contact with the sampled biomass recorded the temperature, while a digital timer was used to record the time at which the three phases occurred.

According to a preliminary test, the third phase of fire in downy brome biomass started at temperatures above $200 \mathrm{C}$ and the flames occurred and proceeded so quickly that none of the three phases could be distinguished, nor could the duration of flame be recorded. Therefore, two different combustion setups were used. The first was a lowcombustion setup with starting temperatures at $160 \mathrm{C}$, which did not allow the appearance of flames. We recorded the time and temperature of smoke and smoldering phases, the duration of smoldering, and the mass loss during the smoldering, as the following: (initial biomass of sample - 
final biomass) $\times$ initial biomass ${ }^{-1}$. The second setup, a fastcombustion setup, had a starting temperature of $210 \mathrm{C}$, and we recorded the probability of the flame occurrence. All the tests were repeated 10 times for each population and setup. Time and temperature of smoke and smoldering, and the probability of flame characterized the ignitability of biomass, as it is often defined either as the minimum temperature or heat flux required for ignition or as how much time it takes a plant to ignite once it is exposed to an external heat source (White and Zipperer 2010). The duration of smoldering is the time of low-temperature flameless combustion, which is often described as the rapidity of the combustion after ignition, while mass loss during combustion characterizes the consumability, which is the proportion of mass or volume consumed by combustion (White and Zipperer 2010).

As the moisture content might highly influence biomass flammability (Chuvieco et al. 2004; Pausas et al. 2012), a subsample of the homogenized biomass was used from each population to estimate the moisture content at the time of testing the flammability. Five subsamples ( 0.5 to 1 g) were weighed (fresh mass, $\mathrm{M}_{\mathrm{f}}$ ), oven-dried for $24 \mathrm{~h}$ at $80 \mathrm{C}$, then measured again (dry biomass, $\mathrm{M}_{\mathrm{d}}$ ). Biomass moisture (\%) was determined as $\mathrm{BM}=100 \times\left[\left(\mathrm{M}_{\mathrm{f}}-\mathrm{M}_{\mathrm{d}}\right)\right.$ $\left.\times \mathrm{M}_{\mathrm{d}}^{-1}\right]$. As leaves are considered to be the most important flammable plant structure (Etlinger and Beall 2004), the same dry subsamples were sorted into stems, leaves, and seeds, and the proportional weight of leaves in each mixing was calculated. Biomass moisture content and the proportion of leaves in the biomass were used as covariates in the analyses.

Statistical Analyses. Experiment 1. The effects of (1) low temperatures $(40,60,80 \mathrm{C})$ and germination in the dark; (2) high temperatures $(100,120,140,160 \mathrm{C})$ and germination in the light; and (3) other fire-related cues (ash, smoke, flame) and germination in the light on the germination proportion of downy brome seeds were tested by three separate generalized mixed-effect models (GLMM) with binomial error distribution. Control treatments were included in all three analyses. Lethal treatment levels (germination proportion $<5 \%$ for all six populations) were excluded from analyses. The response variable was a two-vector variable with both the number of successes (germinated seeds) and failures (nongerminated seeds); whereas treatments and continent were fixed variables, the seed weight was a covariate, while population nested within continent was a random variable. We applied backward stepwise selection procedures to find the minimum adequate models for each dependent variable.
We extracted the coefficient of determination $\left(R^{2}\right)$ to estimate the predictive capacity of the models. We used the r.squaredGLMM function in the "MuMIn" package in R (R Core Team 2014) to calculate marginal $R^{2}\left(R^{2} \mathrm{~m}\right)$, which is concerned with variance explained by fixed factors, and conditional $R^{2}\left(R^{2} \mathrm{c}\right)$, which is the variance explained by both fixed and random factors (Nakagawa and Schielzeth 2013). We used glht function with Tukey contrasts in the R package "multcomp" after generalized linear models to test for differences among the levels of significant explanatory variables. Estimates (i.e., "effect size") and standard errors for significant variables were also extracted (Dibble et al. 2015).

Experiment 2. The effect of experimental fire on early growth of downy brome seedlings (averaged between the four seedlings per pot) was tested with GLMMs, where seedling height, total biomass, and shoot : root ratio were included as dependent variables and treatment and continent and their interactions were fixed variables, whereas block and populations nested within continent were included as random variables in the models. Dependent variables were log-transformed to obtain normally distributed residuals or to achieve homoscedastic distributions, or both. The coefficients of determination and the effect sizes were extracted as presented above.

Experiment 3. As time and temperature of smoke and smoldering were highly correlated, the temperature data were not included in the analyses. For flammability characteristics (except probability of flame) we used GLMMs to test the effect of continent of origin (fixed factor), the biomass moisture content, and the proportion of leaves (covariates) on the dependent variables (time to smoke and smoldering, duration of smoldering, mass loss during combustion). Populations nested within continent of origin were included as random terms in the analyses. Time of smoldering, duration of smoldering, and mass loss during smoldering were Box-Cox transformed to meet the assumption of normality or homoscedasticity or both. GLMM with binomial error distribution was run with the same explanatory variables when the probability of flame was the dependent variable. We applied backward stepwise selection procedures to find the minimum adequate models for each dependent variable. The coefficients of determination and the effect sizes were extracted as presented above.

All analyses were performed using the $\mathrm{R}$ statistical environment, version 3.0.3 (R Core Team 2014). 

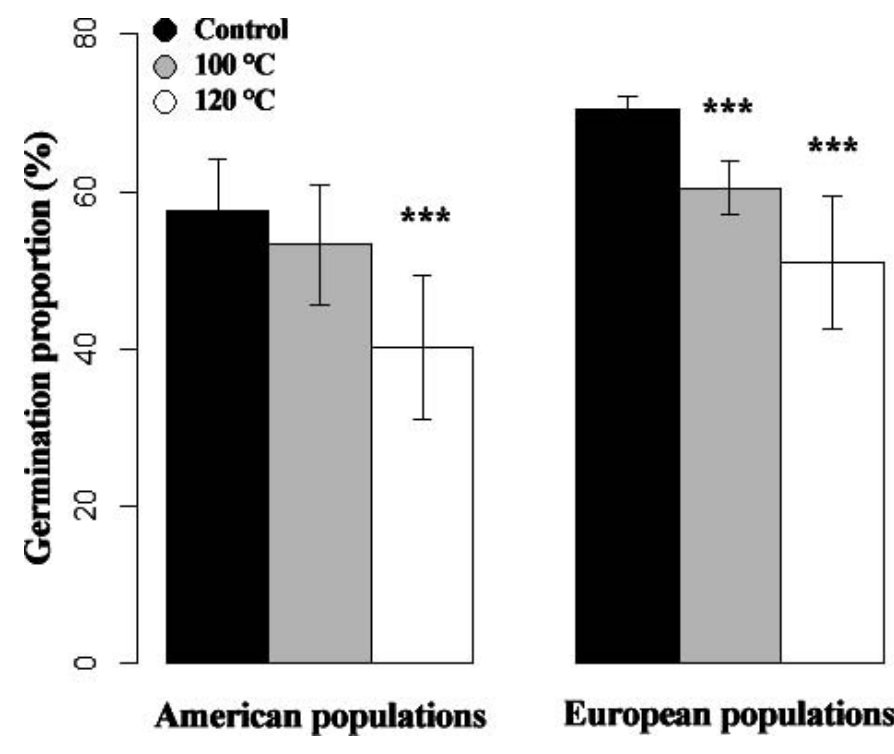

European populations

Figure 1. Germination proportion of downy brome seeds from three North American and three Central European populations in control conditions and after 100 and $120 \mathrm{C}$ heat shocks for 5 min. Asterisks mark significant differences compared to control situation separately for each continent (***, P $<0.001)$. Mean \pm SE are shown.

\section{Results and Discussion}

Intense Fires Reduce the Germination of Seeds. The germination proportions of downy brome seeds in control cases were similar in light and dark conditions (Supplemental Material; http://dx.doi.org/10.1614/IPSM-D-1600006.S1). There were no significant differences between continents regarding the germination proportion of the seeds in control situations (dark: $\chi_{\text {continent }}^{2}=1.99, \mathrm{P}=$ $0.15, R^{2} \mathrm{~m}=0.04, R^{2} \mathrm{c}=0.12$; light: $\chi_{\text {continent }}^{2}=2.28, \mathrm{P}=$ $\left.0.13, R^{2} \mathrm{~m}=0.05, R^{2} \mathrm{c}=0.10\right)$. Similarly, the seed mass did not influence the germination proportion of seeds (it was removed during model simplification in all three GLMMs).

Fire resistance of seeds allows efficient germination and establishment after fire in frequently burned ecosystems (Keeley et al. 2011). Germination of grasses from nonfire-prone ecosystems is negatively affected even by low heat shocks (100 C for 5 min; Ruprecht et al. 2013). For example, field brome (Bromus arvensis L.) showed more than a $60 \%$ decrease in germination proportion at this temperature, whereas many Poaceae species from fireprone ecosystems have been shown to tolerate higher fire temperatures (120 C for 5 min; Keeley and Keeley 1987). We found that low temperatures $(40,60,80 \mathrm{C})$, smoke, and ash treatments did not influence the germination of downy brome seeds compared to control in either of the continents (Supplemental data). Higher temperatures
$(100,120 \mathrm{C})$ significantly reduced the germination of the seeds $\left(\chi_{\text {treatment }}^{2}=83.14, \mathrm{P}<0.001, R^{2} \mathrm{~m}=0.03, R^{2} \mathrm{c}\right.$ $=0.10)$, and these treatments acted differently on the seeds of the two continents $\left(\chi^{2}\right.$ treatment by continent $=12.97$, $\mathrm{P}=0.001, R^{2} \mathrm{~m}=0.05, R^{2} \mathrm{c}=0.10$; Figure 1$)$. Post-hoc tests revealed that the $100 \mathrm{C}$ treatment reduced only the germination of European seeds $(z=-6.55, \mathrm{P}<0.001$, effect size $\pm \mathrm{SE}=-0.69 \pm 0.10)$, while the $120 \mathrm{C}$ treatment was influential for seeds of both continents (Europe: $z=-10.55, \mathrm{P}<0.001$, effect size $\pm \mathrm{SE}=-1.08$ \pm 0.10 ; North America: $z=-8.67, \mathrm{P}<0.001$, effect size $\pm \mathrm{SE}=-0.75 \pm 0.08$; Figure 1$)$.

Extreme temperatures for $5 \mathrm{~min}(140,160 \mathrm{C})$ and flame treatment were lethal to seeds (Supplemental data). Other studies also reported that fire temperature needs to be over $150 \mathrm{C}$ for $5 \mathrm{~min}$ or $125 \mathrm{C}$ for $60 \mathrm{~min}$ to kill the majority of the downy brome seeds (Thill et al. 1984; Young and Evans 1975). As a consequence, a great number of seeds directly affected by fire (especially those in the litter) are destroyed during burning, because the temperatures in downy brome-dominated sites in the Great Basin show similar temperatures at $5 \mathrm{~cm}$ above soil $(150$ to $160 \mathrm{C}$ ) (Beckstead et al. 2011). Indeed, field studies recorded less than $3 \%$ of viable downy brome seeds in severely burned areas compared to unburned invaded plots (Humphrey and Schupp 2001).

However, a less intense fire $(<120 \mathrm{C})$ should not have detrimental consequences on the invasion dynamics of the species in the Great Basin. Even though the carryover seeds deplete quickly in the soil seed bank during a fire (Humphrey and Schupp 2001), high seed production from the proportion that remains can quickly replenish the seed bank (Young and Evans 1978). Hassan and West (1986) reported a 3.5-fold increase in the downy brome seed bank after one growing season following a fire.

Enhanced Growth in North American Populations. Fire opens up space for recruitment opportunities of the offspring, and also alters the microenvironment in a way that might help the development of the descendants (Schwilk and Kerr 2002). Fire affecting downy bromedominated sites depends on the amount of litter accumulation, but in general, these fires can be characterized by low residence time and low transfer of heat to the soil (Blank et al. 1996). Accordingly, water-soluble nitrate, calcium, and magnesium levels increase, while other elements remain the same due to the short duration of litter combustion (Blank et al. 1996).

We found significantly increased height and biomass after $4 \mathrm{wk}$ of growth under postfire conditions in American plants. Stem height of downy brome individuals after 4 wk of growth was significantly influenced by the treatment (burned vs. control; $\chi_{\text {treatment }}^{2}=55.79$, $\mathrm{P}<$ 

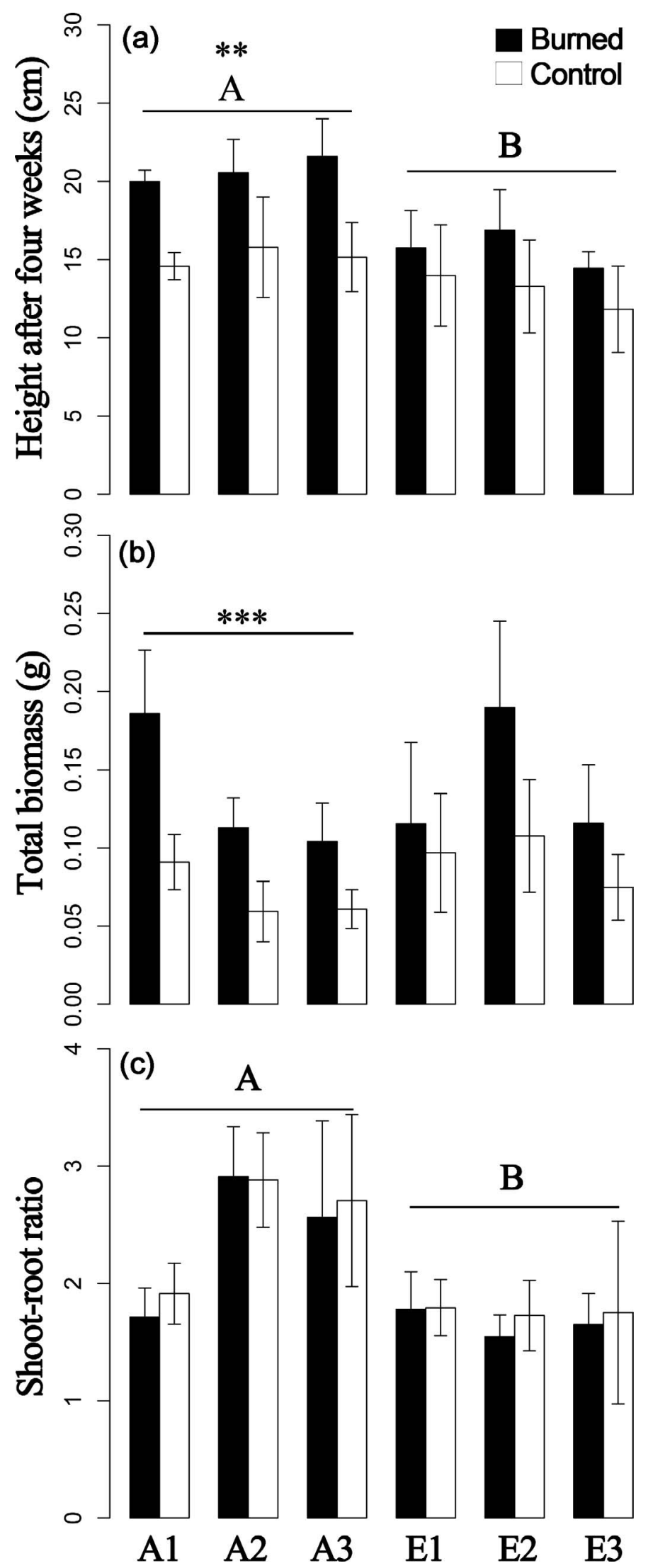

Figure 2. (a) Stem height, (b) total biomass, and (c) shoot : root ratio of downy brome individuals from North America (A1, A2, $\left.0.001, R^{2} \mathrm{~m}=0.21, R^{2} \mathrm{c}=0.64\right)$, marginally by continent of origin $\left(\chi_{\text {continent }}^{2}=3.07, \mathrm{P}=0.07, R^{2} \mathrm{~m}=0.24, R^{2} \mathrm{c}=\right.$ $0.24)$, and significantly by their pairwise interaction $\left(\chi_{\text {treatment by continent }}^{2}=6.92, \mathrm{P}=0.008, R^{2} \mathrm{~m}=0.51, R^{2} \mathrm{c}\right.$ $=0.65)$. Fire significantly affected only the North American populations $(z=-7.14, \mathrm{P}=0.006$, effect size $\pm \mathrm{SE}=-1.51 \pm 0.21)$, but not the European ones $(z=$ $-2.42, \mathrm{P}=0.18$, effect size $\pm \mathrm{SE}=-0.52 \pm 0.24)$ : North American individuals were taller in burned pots relative to control pots (Figure 2a). Similarly, the total biomass significantly depended on treatment $\left(\chi_{\text {treatment }}^{2}=7.88, \mathrm{P}\right.$ $\left.<0.001, R^{2} \mathrm{~m}=0.31, R^{2} \mathrm{c}=0.54\right)$, and on the interaction between treatment and continent $\left(\chi_{\text {treatment by continent }}^{2}=\right.$ 8.16, $\left.\mathrm{P}<0.001, R^{2} \mathrm{~m}=0.20, R^{2} \mathrm{c}=0.74\right)$, as only North American individuals had significantly higher biomass under burned conditions $(z=-6.24, \mathrm{P}<0.001$, effect size $\pm \mathrm{SE}=-0.63 \pm 0.10$ ), while European individuals had not $(z=-2.72, \mathrm{p}=0.09$, effect size $\pm \mathrm{SE}=-0.26 \pm$ 0.21 , Figure $2 \mathrm{~b}$ ). Initial seedling growth is a crucial factor in the postfire environments, because higher growth rate might confer competitive advantages over native species (Moreira et al. 2010). Such fire-related cues might contribute to downy brome productivity and fuel load with subsequent effects on flammability and fire frequency (Rossiter et al. 2003). Elevated nitrate conditions have already been shown to enhance the biomass growth of downy brome (Fenesi et al. 2011; Johnson et al. 2010).

In control conditions, North American populations of downy brome were taller after 4 wk of growth $\left(\chi^{2}=6.01, \mathrm{P}\right.$ $\left.=0.014, R^{2} \mathrm{~m}=0.14, R^{2} \mathrm{c}=0.14\right)$, but had similar total biomass to European populations $\left(\chi^{2}=2.28, \mathrm{P}=0.13\right.$, $\left.R^{2} \mathrm{~m}=0.07, R^{2} \mathrm{c}=0.61\right)$. This is not surprising, as invasive downy brome is known to exhibit greater adaptive plasticity than native populations (Griffith et al. 2014; $\mathrm{He}$ et al. 2011). However, increased investment in shoot instead of root comprised a priority in American populations, as the shoot : root ratios of North American plants were significantly higher in control conditions compared with European plants $\left(\chi_{\text {continent }}^{2}=8.60, \mathrm{P}<\right.$ $0.001, R^{2} \mathrm{~m}=0.19, R^{2} \mathrm{c}=0.73$; Figure $2 \mathrm{c}$ ), but did not depend on treatment or continent by treatment interaction. These responses could be the result of drought avoidance behavior (local adaptation), as these North American populations derived from temperate semidesert conditions. Preferential allocation to aboveground parts enables more rapid growth under stressful conditions (e.g., xeric or saline

A3) and Central Europe (E1, E2, E3) after 4 wk of growth in burned and control conditions. Different letters denote significant differences between continents, while asterisks mark significant differences between burned and control treatments at continent level (**, $\mathrm{P}<0.01$; $\left.{ }^{* *}, \mathrm{P}<0.001\right)$. Mean $\pm \mathrm{SE}$ are shown. 
habitats), which ensures successful maturation in a rapidly drying environment (Rasmuson and Anderson 2002; Rice et al. 1992). Another possible explanation of the different resource allocation strategies between North American and European individuals can be linked to the soil biota of the potting soil used in our experiment. The microbial pathogens and mutualists that the seedlings encountered belowground could have differential effect on the growing patterns of North American downy brome seedlings, as plant-soil feedbacks might manifest differently for plants in their native vs. nonnative range (Andonian et al. 2011). Other brome species (California brome, Bromus carinatus Hook \& Am.; compact brome, Bromus madritensis) were already proven to increase their shoot: root ratio in nonsterile vs. sterile soil (Brandt et al. 2009). Upcoming studies should take into account the different effect of plant-soil feedback on populations of different origin of the same species by using sterilized or neutral soil.

Studies examining plant responses to certain treatments by growing genotypes from different populations in a common garden share the drawback of having their data influenced by maternal effects (Dlugosch and Parker 2008). There is a general assumption in plant ecology that considers maternal effect less likely to influence performance in the offspring's later life history (e.g., Chun et al. 2011), although there is also evidence that maternal effects may influence adult performance in the long term (e.g. Fenesi and Botta-Dukát 2012). By using seeds from 50 to 100 mother plants from three random populations per continent, we tried to reduce the influence of environmental maternal effects. However, we cannot rule out the impact of maternal effect from our results due to our experimental design.

\section{Enhanced Flammability in North American Popula-}

tions. Increased fuel loads, areal extent of fuel coverage, and the quality of fuels are among the principal factors altering fire behavior (Ziska et al. 2005). Downy brome produces litter-driven surface fires due to the dry fuels accumulated close to the ground. Leaves of downy brome have a high surface: volume ratio and low moisture content, thus producing a highly flammable fine fuel (Blank et al. 2006). Moreover, we demonstrated that the North American populations from regions with frequent fire history were more flammable than European populations. Three out of five flammability parameters significantly depended on the continent of origin of downy brome populations. American populations had higher ignitability than European populations: fuel began to smoke more rapidly $\left(\chi_{\text {continent }}^{2}=6.74, \mathrm{P}=0.009, R^{2} \mathrm{~m}=\right.$ $0.16, R^{2} \mathrm{c}=0.22$; Figure $3 \mathrm{a}$ ), and flames occurred with higher probability $\left(\chi_{\text {continent }}^{2}=10.08, \mathrm{P}<0.001, R^{2} \mathrm{~m}=\right.$ $\left.0.10, R^{2} \mathrm{c}=0.24\right)$. Moreover, the mass loss during combustion (consumability) was significantly higher in North American populations compared with European ones $\left(\chi_{\text {continent }}^{2}=5.29, \mathrm{P}=0.02, R^{2} \mathrm{~m}=0.13, R^{2} \mathrm{c}=0.18\right.$; Figure $3 \mathrm{~d})$. These results suggest that American plants are stronger fire promoters, and that fuels from the North American populations burn more thoroughly and retain a flame for a shorter period of time (Bond and Keeley 2005) than the European populations, which do not experience fire.

Studies tried to link flammability responses to plant traits by comparing species of the same genus (e.g., Pinus spp., Fonda 2011; Quercus spp., Kane et al. 2008) or phylogenetically nonrelated tree species of the same floristic region (de Magalhães and Schwilk 2012, Scarff and Westoby 2006,). However, intraspecific investigations of traits conferring flammability are scarce (but see Blank et al. 2006; Pausas et al. 2012). Flammability is a function of many factors, but the moisture content, the surface area : volume ratio, and the biochemical composition of tissues-the relative proportion of lignin, cellulose, hemi-cellulose, etc. and the content of elements like silica and potassium-affect flammability properties (Blank et al. 2006). Biomass water content is an important correlate of fuel flammability, because ignition will not start before moisture is lost through evaporation. Therefore, plant species with high moisture content might be less flammable as they take longer to ignite (Etlinger and Beall 2004; Pausas et al. 2012; Schwilk and Caprio 2011). Interestingly, the moisture content of biomass analyzed by us had no significant effects on the flammability of downy brome. Additionally, the proportion of structural building units of plants can also contribute to flammability, as leaves are considered to be the most important flammable plant structures. However, in our study, the proportion of leaves did not significantly influence flammability characteristics.

As we took into account the moisture content and composition of the samples (the proportion of leaves) as covariates in our analysis, flammability differences among continents are very probably due to biochemical properties of tissues. Although we did not set out to test the biochemical composition of tissues, the study of Blank et al. (2006) might help us understand the flammability results. These authors found that combustion parameters of three downy brome populations correlated significantly with many tissue attributes. For instance, time to ignition correlated with tissue concentrations of glucan, $\mathrm{Ca}$, and the $\mathrm{P}$ : Ca proportion. The authors found out that elevated tissue concentrations of silica, other inorganics, and lignin can reduce flammability. The biochemical parameters that influenced the flammability of the plants differed among the populations, but authors did not detail the background factors which influenced them (Blank et al. 2006). 

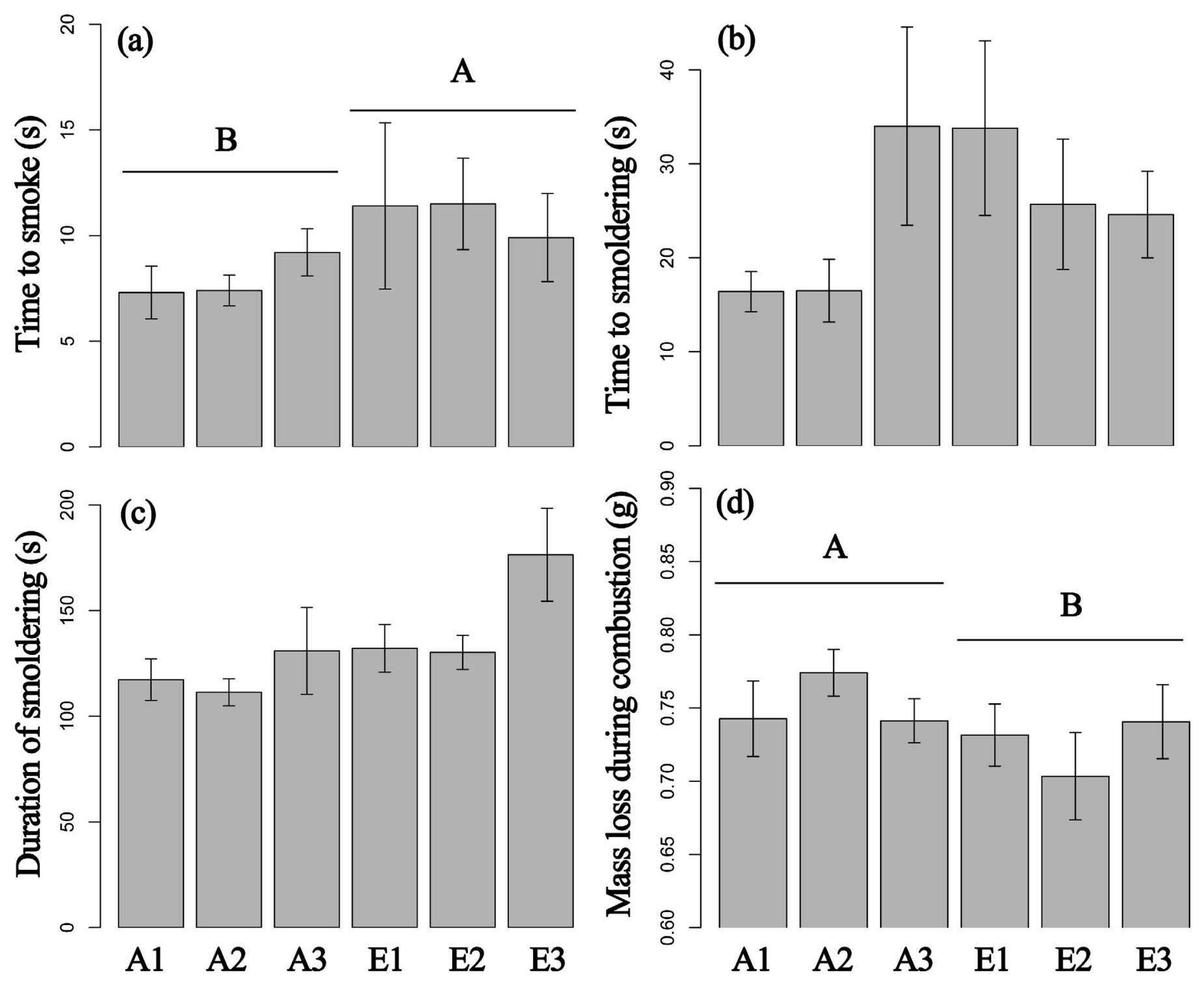

Figure 3. Flammability-related responses-(a) time to smoke, (b) time to smoldering, (c) duration of smoldering and (d) mass loss during combustion — of six downy brome populations: three from North America (A1, A2, A3) and three from Central Europe (E1, E2, E3). Different letters denote significant differences between continents. Mean \pm SE are shown.

Frequent fires can be directly linked to the invasive success of downy brome. Due to recurrent fires, this annual grass quickly reaches dominance for two main reasons. First, most woody species in the Great Basin are killed by fire, because generally they are non-resprouters (Chambers et al. 2007). Resprouting shrubs such as rabbitbrush (Chrysothamnus spp.) may share the site with downy brome, but frequent recurrent fires might eliminate them as well (Knapp 1996). Second, in the Great Basin of North America, fire destroys current-year seeds of perennials (both shrubs and herbaceous plants); downy brome dries and is prone to burn before the perennials can set seeds (Humphrey and Schupp 2001). Therefore, recurrent fires deplete seed banks of perennial species to negligible levels, especially those of grasses, as they are typically small due to variable seed production and short-lived seeds (Hassan and West 1986). Early germination in the fall and under cold winter temperatures, high germination rates of up to $100 \%$ (Beckstead et al. 1996), the ability to produce root growth in winter (Aguirre and Johnson 1991), and fast usage of postfire soil resources provide an advantage to downy brome over native perennial seedlings and allows downy brome to outcompete them (Chambers et al. 2007; Humphrey and Schupp 2004). Without fire, established perennial communities can resist in the face of downy brome invasion (Humphrey and Schupp 2004). Therefore, the "kill thy neighbor" hypothesis perfectly fits downy brome. This hypothesis states that mutants with increased 
flammability could be selected if the elevated flammability resulted in increased mortality of neighbors, and thus opened up space for recruitment opportunities of the flammable individual's offspring (Bond and Midgley 1995).

We cannot rule out the possibility that enhanced flammability of invasive populations might result from selection for other directly beneficial traits such as drought tolerance or defense against herbivores (Snyder 1984). Such predictions make sense because of the climatic (Table 1) and land-use differences between Central Europe and the Great Basin of North America. Despite the fact that downy brome populations are generally subjected to more arid conditions in North America, neither the temperature nor the precipitation data correlate with our results. For example, the $\mathrm{A} 1$ and $\mathrm{A} 2$ populations showed similar ignitability, but receive different amounts of annual precipitation. Therefore, until further studies, frequent fires as a selection force for increased flammability remains a plausible hypothesis.

\section{Conclusions}

Downy brome, a highly successful invasive species of the Great Basin has induced shifts in the frequency and intensity of wildfires causing ecosystem-level perturbations. Fire eliminates native woody and herbaceous perennial competitors; therefore, the postfire microenvironments favor the establishment and performance of downy brome seedlings. It thrives under postfire conditions, changing the community characteristics to the point where native species cannot recover. We found out that the success of North American populations from frequently burned environments might be backed by enhanced fire response attributes. The sampled American populations showed increased flammability compared to European populations that are rarely or never exposed to fire, which increases the probability of ignition and fire spread. Moreover, higher resource allocation into aboveground biomass in postfire environmental conditions may also contribute to the frequent occurrence of fire by producing higher fuel loads and continuous fuel beds. These enhanced fire-related traits (flammability and allocation to aboveground tissues) promote frequent fires, but with low intensity, which is a prerequisite of downy brome's success, as its seeds do not tolerate severe fires with high heat shocks ( $>100 \mathrm{C})$.

\section{Acknowledgments}

The authors would like to thank Júliánna Geréd and Enikö Fodor for excellent technical assistance, and Charlie Clements, Dan Harmon (Agricultural Research Service-Great Basin Rangelands Research Unit, Reno NV), Csongor I. Vágási, and
Ágnes Albert for supplying seeds of downy brome. A. Fenesi was supported by the European Union and the State of Hungary, cofinanced by the European Social Fund in the framework of TÁMOP 4.2.4. A/2-11-1-2012-0001 National Excellence Program. This work was supported by a grant of the Romanian National Authority for Scientific Research and Innovation, CNCS - UEFISCDI, project number PN-II-RUTE-2014-4-0381.

\section{Literature Cited}

Aguirre L, Johnson DA (1991) Influence of temperature and cheatgrass competition on seedling development of two bunchgrasses. J Range Manag 44:347-354

Altbäcker V (1998) Növény-növényevő kapcsolatok vizsgálata homoki társulásokban. Pages 123-145 in Fekete G, ed. A Oözösségi Ökológia Frontvonalai. Budapest

Andonian K, Hierro JL, Khetsuriani L, Becerra P, Janoyan G, Villarreal D, Cavieres L, Fox LR, Callaway RM (2011) Range-expanding populations of a globally introduced weed experience negative plantsoil feedbacks. PLoS One 6:e20117-e20124

Bartlett E, Novak SJ, Mack RN (2002) Genetic variation in Bromus tectorum (Poaceae): differentiation in the eastern United States. Am J Bot 89:602-612

Beckstead J, Meyer SE, Allen PS (1996) Bromus tectorum seed germination: between-population and between-year variation. Can J Bot 74:875-882

Beckstead J, Street LE, Meyer SE, Allen PS (2011) Fire effects on the cheatgrass seed bank pathogen Pyrenophora semeniperda. Rangel Ecol Manag 64:148-157

Billings WD (1994) Cheatgrass and resultant fire on ecosystems in the western Great Basin. Pages 22-30 in Monsen SB, Kitchen SG, eds. Proceedings of Ecology and Management of Annual Rangelands. Ogden, UT: U.S. Department of Agriculture Forest Service

Blank RR, Allen FL, Young JA (1996) Influence of simulated burning of soil-litter from low sagebrush, squirreltail, cheatgrass, and medusahead on water-soluble anions and cations. Int J Wildl Fire 6:137

Blank RR, White RH, Ziska LH (2006) Combustion properties of Bromus tectorum L.: influence of ecotype and growth under four $\mathrm{CO}_{2}$ concentrations. Int J Wildl Fire 15:227-236

Bond WJ, Keeley JE (2005) Fire as a global "herbivore": the ecology and evolution of flammable ecosystems. Trends Ecol Evol 20:387394

Bond WJ, Midgley JJ (1995) Kill thy neighbour: an individualistic argument for the evolution of flammability. Oikos 73:79-85

Brandt AJ, Seabloom EW, Hosseini PR (2009) Phylogeny and provenance affect plant-soil feedbacks in invaded California grasslands. Ecology 90:1063-1072

Brooks M, D’Antonio C, Richardson D, Grace J, Keely J, DiTomaso J, Hobbs R, Pellant M, Pyke D (2004) Effects of invasive alien plants on fire regimes. Bioscience 54:677-688

Bureau of Land Management (2015) Geospatial Data. http://www.blm. gov/nv/st/en/prog/more_programs/geographic_sciences/gis/ geospatial_data.html. Accessed November 20, 2015

Chambers JC, Roundy BA, Blank RR, Meyer SE, Whittaker A (2007) What makes Great Basin sagebrush ecosystems invasible by Bromus tectorum? Ecol Monogr 77:117-145 
Chun YJ, Le Corre V, Bretagnolle F (2011) Adaptive divergence for a fitness-related trait among invasive Ambrosia artemisiifolia populations in France. Mol Ecol 20:1378-1388

Chuvieco E, Aguado I, Dimitrakopoulos AP (2004) Conversion of fuel moisture content values to ignition potential for integrated fire danger assessment. Can J For Res 34:2284-2293

Climent J, Tapias R, Pardos J, Gil L (2004) Fire adaptations in the Canary Islands pine (Pinus canariensis). Plant Ecol 171:185-196

D'Antonio CM (2000) Fire, plant invasions, and global changes. Pages 65-93 in Mooney HA, Hobbs RJ, eds. Invasive Species in a Changing World. Washington, DC: Island Press

D’Antonio CM, Vitousek PM (1992) Biological invasions by exotic grasses, the grass/fire cycle, and global change. Annu Rev Ecol Syst 23:63-87

Deák B, Valkó O, Török P, Végvári Z, Hartel T, Schmotzer A, Kapocsi I, Tóthmérész B (2014) Grassland fires in Hungary-experiences of nature conservationists on the effects of fire on biodiversity. Appl Ecol Environ Res 12:267-283

de Magalhães RMQ, Schwilk DW (2012) Leaf traits and litter flammability: evidence for non-additive mixture effects in a temperate forest. J Ecol 100:1153-1163

Dibble KL, Yackulic CB, Kennedy TA, Budy P (2015) Flow management and fish density regulate salmonid recruitment and adult size in tailwaters across western North America. Ecol Appl 25:2168-2179

Dlugosch KM, Parker IM (2008) Founding events in species invasions: Genetic variation, adaptive evolution, and the role of multiple introductions. Mol Ecol 17:431-449

Escudero A, Núñez Y, Pérez-García F (2000) Is fire a selective force of seed size in pine species? Acta Oecol 21:245-256

Etlinger MG, Beall FC (2004) Development of a laboratory protocol for fire performance of landscape plants. Int J Wildl Fire 13:479-488

Fenesi A, Botta-Dukát (2012) Phenotypic divergences induced by different residence time in invasive common ragweeds. J Plant Ecol 5:174-181

Fenesi A, Rédei T, Botta-Dukát Z (2011) Hard traits of three Bromus species in their source area explain their current invasive success. Acta Oecol 37:441-448

Feurdean A, Liakka J, Vannière B, Marinova E, Hutchinson SM, Mosburgger V, Hickler T (2013) 12,000-Years of fire regime drivers in the lowlands of Transylvania (Central-Eastern Europe): a datamodel approach. Quat Sci Rev 81:48-61

Fonda RW (2011) Burning characteristics of needles from eight pine species. For Sci 47:7

Gagnon PR, Passmore HA, Platt WJ, Myers JA, Paine CET, Harms KE (2010) Does pyrogenicity protect burning plants? Ecology 91:34813486

Gómez-González S, Torres-Díaz C, Bustos-Schindler C, Gianoli E (2011) Anthropogenic fire drives the evolution of seed traits. Proc Natl Acad Sci USA 108:18743-18747

Griffith AB, Andonian K, Weiss CP, Loik ME (2014) Variation in phenotypic plasticity for native and invasive populations of Bromus tectorum. Biol Invasions 16:2627-2638

Hassan MA, West NE (1986) Dynamics of soil seeds pools in burned and unburned sagebrush semi-deserts. Ecology 67:269-272

He W-M, Yu G-L, Sun Z-K (2011) Nitrogen deposition enhances Bromus tectorum invasion: biogeographic differences in growth and competitive ability between China and North America. Ecography (Cop) 34:1059-1066
Hernandez-Serrano A, Verdu M, Gonzalez-Martinez SC, Pausas JG (2013) Fire structures pine serotiny at different scales. Am J Bot 100:2349-2356

Hijmans RJ, Cameron SE, Parra JL, Jones PG, Jarvis A (2005) Very high resolution interpolated climate surfaces for global land areas. Int J Climatol 25:1965-1978

Humphrey LD, Schupp EW (2001) Seed banks of Bromus tectorumdominated communities in the Great Basin. West North Am Nat 61:85-92

Humphrey LD, Schupp EW (2004) Competition as a barrier to establishment of a native perennial grass (Elymus elymoides) in alien annual grass (Bromus tectorum) communities. J Arid Environ 58:405422

Johnson BG, Johnson DW, Chambers JC, Blank RR (2010) Fire effects on the mobilization and uptake of nitrogen by cheatgrass (Bromus tectorum L.). Plant Soil 341:437-445

Kaczmarski J (2000) Restoration implications of Bromus tectoruminfested grasslands of the Great Basin. Restor Reclam Rev 6:1-14

Kane JM, Varner JM, Hiers JK (2008) The burning characteristics of southeastern oaks: discriminating fire facilitators from fire impeders. For Ecol Manag 256:2039-2045

Keeley JE, Fotheringham C (1998) Smoke-induced seed germination in California chaparral. Ecology 79:2320-2336

Keeley JE, Keeley SC (1987) Role of fire in the germination of chaparral herbs and suffrutescents. Madroño 34:240-249

Keeley JE, Pausas JG, Rundel PW, Bond WJ, Bradstock RA (2011) Fire as an evolutionary pressure shaping plant traits. Trends Plant Sci 16:406-411

Knapp PA (1996) Cheatgrass (Bromus tectorum L.) dominance in the Great Basin Desert: history, persistence, and influences to human activities. Glob Environ Chang 6:37-52

Laland KN, Odling-Smee FJ, Feldman MW (1999) Evolutionary consequences of niche construction and their implications for ecology. Proc Natl Acad Sci USA 96:10242-10247

Lloret F, Estevan H, Vayreda J, Terradas J (2005) Fire regenerative syndromes of forest woody species across fire and climatic gradients. Oecologia 146:461-468

Mack RN (1981) Invasion of Bromus tectorum L. into Western North America: an ecological chronicle. Agro-Ecosystems 7:145-165

Maron JL, Vilà M, Bommarco R, Elmendorf S, Beardsley P (2004) Rapid evolution of an invasive plant. Ecol Monogr 74:261-280

Moreira B, Tormo J, Estrelles E, Pausas JG (2010) Disentangling the role of heat and smoke as germination cues in Mediterranean Basin flora. Ann Bot 105:627-635

Mousseau TA, Fox CW (1998) The adaptive significance of maternal effects. Trends Ecol Evol 13:403-407

Nakagawa S, Schielzeth H (2013) A general and simple method for obtaining $R^{2}$ from generalized linear mixed-effects models. Methods Ecol Evol 4:133-142

Novak SJ, Mack RN (1993) Genetic variation in Bromus tectorum (Poaceae): comparison between native and introduced populations. Heredity (Edinb) 71:167-176

Novak SJ, Mack RN (2001) Tracing plant introduction and spread: genetic evidence from Bromus tectorum (cheatgrass). Bioscience 51:114

Pausas J, Giorgio A, Moreira B, Corcobado G (2012) Fires enhance flammability in Ulex parviflorus. New Phytol 193:18-23

Pausas JG, Bradstock RA, Keith DA, Keeley JE, Global Change of Terrestrial Ecosystem Fire Network (2004) Plant functional traits in relation to fire in crown-fire ecosystems. Ecology 85:1085-1100 
Pausas JG, Keeley JE (2014) Abrupt climate-independent fire regime changes. Ecosystems 17:1109-1120

Pérez-Fernández M, Rodríguez-Echeverría S (2003) Effects of smoke, charred wood, and nitrogenous compounds on seed germination of ten species from woodland in central-western Spain. J Chem Ecol 29:237-251

Prentis PJ, Wilson JRU, Dormontt EE, Richardson DM, Lowe AJ (2008) Adaptive evolution in invasive species. Trends Plant Sci 13:288-294

R Core Team (2014) R: A Language and Environment for Statistical Computing. Vienna, Austria: R Foundation for Statistical Computing

Rasmuson KE, Anderson JE (2002) Salinity affects development, growth, and photosynthesis in cheatgrass. J Range Manag 55:80-87

Rice KJ, Black RA, Radamaker G, Evans RD (1992) Photosynthesis, growth, and biomass allocation in habitat ecotypes of cheatgrass (Bromus tectorum). Funct Ecol 6:32-40

Rossiter NA, Setterfield SA, Douglas MM, Hutley LB (2003) Testing the grass-fire cycle: alien grass invasion in the tropical savannas of northern Australia. Divers Distrib 9:169-176

Ruprecht E, Fenesi A, Fodor I, Kuhn T (2013) Prescribed burning as an alternative management in grasslands of temperate Europe?: the impact on seeds. Basic Appl Ecol 14:642-650

Saura-Mas S, Paula S, Pausas JG, Lloret F (2010) Fuel loading and flammability in the Mediterranean Basin woody species with different post-fire regenerative strategies. Int J Wildl Fire 19:783

Scarff FR, Westoby M (2006) Leaf litter flammability in some semi-arid Australian woodlands. Funct Ecol 20:745-752

Schwilk DW, Caprio AC (2011) Scaling from leaf traits to fire behaviour: community composition predicts fire severity in a temperate forest. J Ecol 99:970-980

Schwilk DW, Kerr B (2002) Genetic niche-hiking: an alternative explanation for the evolution of flammability. Oikos 99:431-442
Snyder JR (1984) The role of fire: much ado about nothing. Oikos 43:404-405

Terpó A, Zajac M, Zajac A (2000) Provisional list of Hungarian archaeophytes. Thaisia - Kosice 9:41-48

Thill DC, Beck KG, Callihan RH (1984) The biology of downy brome (Bromus tectorum). Weed Sci 32:7-12

Vilà M, Espinar JL, Hejda M, Hulme PE, Jarošík V, Maron JL, Pergl J, Schaffner U, Sun Y, Pyšek P (2011) Ecological impacts of invasive alien plants: a meta-analysis of their effects on species, communities and ecosystems. Ecol Lett 14:702-708

Vitousek P (1990) Biological invasions and ecosystem processes: toward an integration of population biology and ecosystem studies. Oikos $57: 7-13$

Westoby M, Walker B, Noy-meir I (1989) Opportunistic management for rangelands not at equilibrium. J Range Manag 42:266-274

White RH, Zipperer WC (2010) Testing and classification of individual plants for fire behaviour: plant selection for the wildland-urban interface. Int J Wildl Fire 19:213

Young JA, Evans A (1978) Population dynamics after wildfires in sagebrush grasslands. J Range Manag 283:283-289

Young JA, Evans RA (1975) Germinability of seed reserves in a big sagebrush community. Weed Sci 23:358-364

Young JA, Evans RA, Major J (1972) Alien plants in the Great Basin. J Range Manag 25:194-201

Ziska LH, Reeves JB, Blank B (2005) The impact of recent increases in atmospheric $\mathrm{CO}_{2}$ on biomass production and vegetative retention of cheatgrass (Bromus tectorum): implications for fire disturbance. Glob Chang Biol 11:1325-1332

Received January 14, 2016, and approved July 19, 2016.

Associate Editor for this paper: Kelly Lyons, Trinity University.

194 • Invasive Plant Science and Management 9, July-September 2016 